\title{
THE IMPACT OF ACCOUNTING STANDARDS DEVELOPMENTS AND FINANCIAL REPORTING COMPLEXITIES ON THE AUDIT COMMITTEE
}

\author{
Ben Marx* \\ University of Johannesburg \\ benm@uj.ac.za \\ Erica du Toit ${ }^{\#}$ \\ University of Johannesburg \\ ericadt@uj.ac.za
}

February 2009

\begin{abstract}
The developments in accounting standards and the increased complexity of financial reporting present many challenges and difficulties to the preparers of financial statements and the audit committee as overseers of the financial reporting process. Accordingly, the audit committee should consist of independent directors with the right experience and expertise and, given the complexity of today's financial statements, it is essential that they should also be financially literate, with at least one member being a financial expert. This article discusses the impact of the development and increased technical nature of accounting standards on the constitution and workings of the audit committee. Empirical evidence is also provided that the average audit committee at the largest listed companies in South Africa consists of members who can be considered as financially literate, with at least one member being a financial expert, and that they are compensated for this expertise.
\end{abstract}

\section{Keywords}

Audit committee, audit committee constitution, audit committee responsibilities, audit committee members' qualification, audit committee members' compensation, accounting standards; King III (draft), Third King Report on Corporate Governance (draft)

\footnotetext{
* Prof Ben Marx is professor in Auditing in the Department of Accountancy at the University of Johannesburg, South Africa

\# Ms Erica du Toit is a senior lecturer in Accounting in the Department of Accountancy at the University of Johannesburg, South Africa
} 


\section{INTRODUCTION}

Audit committees are not a new concept: the first audit committee was formed as early as 1872 by the Great Western Railway Company in the United Kingdom (Brewer, 2001:11). However, it is only in the last 10 to 15 years that audit committees have really come to the forefront (Marx, 2008: 1-4; Marx \& Lubbe, 1993:43-44). Many factors have given rise to renewed emphasis being placed on audit committees and their composition, the most significant of these being major corporate collapses and business failures, and the issuing of various corporate governance codes and new or amended legislation (Brewer, 2001; Carcello, 2003; Ferreira, 2008; Klein, 2000; Kukabadse, \& Korac-Kukabadse, 2002; Liu, 2005; Marx, 2008; Rager, 2004; Spira, 2003; Wayne, 2003; Weiss, 2005; Wymeersch, 2006; Yang, 2002). Being tasked with responsibility for financial reporting, the audit committee should oversee the integrity of the financial reporting process and the providing of accurate and reliable financial information to the users thereof (Deloitte, 2006; KPMG, 2005; PricewaterhouseCoopers, 2005; 2008). Given the current financial crises companies all over the world are experiencing, and especially the financial sector, the oversight role of the audit committee becomes even more important (Ernst \& Young, 2009:1-4).

The increase in volume and the increasingly technical nature of accounting standards over the years have resulted in financial reporting becoming very complex. This in turn has given rise to many new challenges and difficulties to the preparers of financial statements and, accordingly, the audit committee as overseers of the financial reporting process. Thus it is critical that the audit committee should consist of independent directors with the right experience and expertise and, given the complexity of today's financial statements, that all the audit committee members are financially literate with at least one member being a financial expert. They should also be appropriately compensated for their complex responsibilities and the increased legal exposure they potentially face.

In this article the impact of the developments in accounting standards and financial reporting on the constitution and workings of the audit committee is discussed. Empirical evidence is also provided on the qualifications, financial literacy and financial expertise, and compensation of audit committee members at the largest listed companies in South Africa.

\section{AN OVERVIEW OF THE DEVELOPMENTS IN ACCOUNTING STANDARDS AND

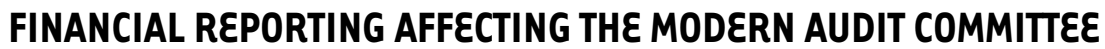

\subsection{Development of accounting standards}

The need for financial information that is reliable, transparent and useful to users has been under discussion for many years and has been the focus of many studies. These include, inter alia, early studies such as that in 1993 by the American Institute of Chartered Accountants (hereafter AICPA) entitled Meeting the Financial Reporting Needs of the Future (AICPA, 1993) and a study in 1994 by the South African Institute of Chartered Accountants (hereafter SAICA) entitled Complying with the Financial Reporting Needs of Financial Statements in South Africa (SAICA, 1994). Since then, the accounting standards and reporting needs of users have been debated at length and the standard setting processes have undergone significant restructuring and changes over the years, as is briefly described below.

In 1973 the professional accounting bodies of nine countries combined their efforts to create 
the International Accounting Standards Committee (hereafter IASC) (Pacter, 2005:67). The main purpose of the IASC was to develop International Accounting Standards (hereafter IASs) that would become the generally accepted accounting principles for each of the nations. In other words, the IASC had the enormous task of harmonising national accounting standards. The IASC was restructured into the International Accounting Standards Board (hereafter IASB) in April 2001 , and along with the name change came a change in the direction in which the body wanted to move. The mission of the standard setter changed from harmonisation to the convergence of global accounting standards (Deloitte, 2005a:1; Harding, 2000; Pacter, 2005:71). Upon its inception the IASB adopted the body of IASs issued by its predecessor, the IASC, and consequently the term International Financial Reporting Standards (hereafter IFRS) includes both IFRSs and IASs. All new accounting standards are set by the IASB and are called IFRS, while the existing standards remained, and used the term IAS (SAICA, 2008: Preface to IFRS:11).

Another important development is the official collaboration of the IASB and the Financial Accounting Standards Board (hereafter FASB), the accounting standard setting body of the United States (hereafter US), and their issuing of a Memorandum of Understanding (also referred to as the Norwalk Agreement) after a joint meeting in September 2002 (IASB, 2008). The long-term strategic priority of both the FASB and IASB was to develop a common set of high quality global standards. The Memorandum of Understanding between these two bodies addressed the need for the convergence of accounting standards, and they agreed that the best way to go about this was to seek convergence by jointly developing new standards rather than trying to eliminate differences between current accounting standards (IASB, 2002). Due to the progress made by the boards by 2007, the Securities Exchange Commission (hereafter SEC) removed the need for the reconciliation requirement for non-United States companies that use IFRS and were registered in the US on 21 December 2007 (FASB, 2008). Several other countries have recently also started to adopt IFRSs, since the benefits of adopting them (for example, the ability to access global capital markets more effectively) are clear (IASB, 2008). The countries currently in the process of adopting IFRS include Brazil, Canada, Chile, India, Japan and Korea (Steenekamp, 2009:29).

South Africa adopted IFRS as South African Statements of Generally Accepted Accounting Practice (hereafter GAAP) effective from 1 January 2005. In response to this the JSE amended its listing requirements and required retrospective compliance with IFRS as of 1 January 2005, which meant that all listed companies had to comply with IFRS 1, First Time Adoption of IFRS (SAICA, 2004:261). The aim with IFRS is to increase the consistency of financial reporting and enable greater comparability of financial information of companies across countries. Accordingly, it is easier for inter alia South African companies to benchmark themselves against international competitors and provide added credibility to their financial statements (Ernst \& young, 2006:1). However, concerns has been raised that compliance with IFRS is costly, time consuming and often misleading (Dilks, 2006:44; Van der Linde, 2007:54).

Modern IFRS is also a highly technical and complex set of accounting standards, and the adoption thereof seems to be problematic, as is illustrated by the following comments made by participants in the Ernst \& Young survey on IFRS (Ernst \& Young, 2006:1-7):

"Some would argue that IFRS neither produce a record of the accountability of management nor a measure of the changes in the economic value of assets and liabilities ... What IFRS actually does is to make our results more difficult to understand" (Lord Browne, Group CEO of BP plc as quoted by Ernst \& Young). 
"I really wonder if the accounting profession is doing itself any favours by making IFRS so complex" (Survey participant).

"The implementation of some of the aspects of IFRS has given rise to considerably increased effort in preparing financial statements with apparently very little additional benefit to users" (Survey participant).

"I believe that the new standards even though theoretically well founded, are in many cases extremely difficult to implement from a practical and measurement perspective" (Survey participant).

The survey also indicated that participants found the following standards the most difficult to interpret and apply (Ernst \& Young, 2006:6):

- Financial instruments standards, including IAS 32, IAS 39 and IFRS 7 - especially embedded derivatives;

- Property, plant and equipment (IAS 16) - especially determining and reassessing the useful life, residual value and practicality thereof;

- Share-based payments (IFRS 2) - including the valuation of share options and the application to non-vanilla share compensation schemes;

- Insurance contracts (IFRS 4) for companies in the insurance industry;

- To a lesser extent also BE\& transactions (AC 503), business combinations (IFRS 3), related parties (IAS 24), employee benefits (IAS 19) and determining whether an arrangement contains a lease (IFRIC 4).

From the above discussions, as well as the fact that currently there are $4 \mathrm{l}$ IASs and eight IFRSs in existence that companies must comply with, it is clear that the modern accounting standards are constantly undergoing changes, as well as increasing in volume and in their level of technicality (SAICA, 2008: Volume IA and Volume 1B). Garth Coppin (national director of accounting at Ernst \& Young) states that "Not only do people need more knowledge and expertise, they probably need a higher I $\mathrm{l}$ to apply today's accounting standards, and the risk of errors is higher than ever before" (Gillingham: 2009:26). Accordingly it is essential that audit committee members have the necessary experience and accounting expertise regarding IFRSs and a sound understanding of the technical nature and complexities involved in the application thereof.

\subsection{The need for relevant financial information}

Users require financial information that is relevant and that meets their investment and other financial decision needs. The issue of relevance of financial reporting was raised again by Sir Michael Rake, head of KPMG International, on a visit to South Africa in August 2007 when he said that a gap still exists between the information that investors receive from financial reports and the information they need to make decisions. He was quoted as saying that "investors expect financial reporting that better reflects economic reality" (Temkin, 2007:2). These expectations of users were addressed in 2006 when the IASB initiated the Framework Convergence Project aimed at improving the information provided to users of financial statements, and also converging the IASB Framework with the United States of America's Generally Accepted Accounting Practices (hereafter US GAAP) Framework. The IASB issued a discussion paper in this regard entitled: "Discussion Paper: Preliminary Views on an Improved Conceptual Framework for 
Financial Reporting: The objective of financial reporting and qualitative characteristics of decision-useful financial reporting information". This discussion paper states the new objective of financial reporting as follows: "The objective of financial reporting is to provide information that is useful to present and potential investors and creditors and others in making investment, credit and similar resource allocation decisions" (IASB, 2006:0B2). The clear focus on investors and creditors as prominent users highlights the board's move towards financial reporting that is more focused on the cash-generating ability of entities.

Along with the change in the objective of financial reporting, the discussion paper also implies that the qualitative characteristic of relevance is ranked above reliability (faithful representation) by illustrating the qualitative characteristics in what it refers to as a "logical order" (IASB, 2006: (CC43 \& 44). In contrast to the discussion paper, the current IASB Framework ranks all qualitative characteristics equally. This subtle change in the ranking of the qualitative characteristics will have a major impact on the measurement models used in financial statements in future, since the fair value accounting model, though less reliable, is without a doubt more relevant than any other measurement model. Moving towards a fair value accounting model in future will have a significant impact on external auditors as well as audit committees, since the success of the fair value model relies heavily on the ability to perform complex valuations as well as the interpretation of contracts. Many assumptions and estimates need to be made in the valuation process, and without sufficient guidance (which is not currently given in any accounting standard) there is a wide range of answers that can be considered acceptable (Heathcote \& Human, 2008:27).

\subsection{Differences between IFRS and US GAAP}

An additional problem exists for companies needing to incorporate the financial information of US companies into their own, as US GAAP, being rule-based, differs significantly from IFRS, being principle-driven (Deloitte, 2005b:1). This will often result in such companies preparing two sets of financial statements, one according to IFRS and one according to US GAAP. Besides the time and costs involved, this will significantly increase the risk of financial misstatement and again emphasises the need for audit committees to have members who understand the different financial reporting frameworks and reporting requirements.

As mentioned in section 2.2 the $S E C$ removed the need for the reconciliation requirement for non-US companies that use IFRSs and are registered in the US (FASB, 2008). The process has also started for the US to adopt IFRS as its reporting standards, but it is anticipated that this will become effective only in 2014 (Anonymous, 2008:5; PricewaterhouseCoopers, 2008:7). In order to facilitate this process the $S E C$ unanimously approved a proposed roadmap to convert to IFRS in August 2008 (Steenekamp, 2009:28). The first step of this roadmap allows 110 of the largest publicly held companies in the US (representing $14 \%$ of the total US market capitalisation) to adopt IFRS at the end of 2009 for their 2010 filings (Steenekamp, 2009:28). In 2011 the SEC will, as a second step, then determine whether to mandate the transition to IFRS by all US companies in 2014 (Steenekamp, 2009:28).

The impact of these developments on audit committees and their members was summarised as follows by PricewaterhouseCoopers (2006:28): “Global companies' audit committees should also ensure they understand the shifting IFRS landscape and what Global GAAP means for their companies. Convergence of USA GAAP with IFRS raises not only technical accounting issues, but also strategic issues such as educating stakeholders on how to interpret financial results under a converged set of standards." This statement implies that it is essential that the composition 
of such global companies' audit committees should provide, inter alia, for financial literacy and expertise amongst its members (and understanding of the different accounting frameworks and their implications).

\subsection{The evolving role of the audit committee regarding financial reporting}

One of the key responsibilities of the audit committee (as further discussed in section 4) is oversight responsibility of the financial reporting process. This responsibility is embedded in various corporate governance codes, institutional requirements, legislation and regulations ( $\mathrm{Du}$ Plessis, McConvill \& Bagaric, 2005:58-303; Marx, 2008:97-207). Traditionally this financial reporting responsibility focused on the financial statements and accordingly compliance with the accounting standards. This responsibility is described as follows by Green and Gregory (2005:56): "The audit committee has the awesome responsibility for oversight of the financial reporting process. To ensure that accounting policies are sound and financial statements appropriately prepared and audited, the board should have an audit committee consisting only of outside directors and at least one financial expert". The audit committee will further need to be constituted of members with the relevant financial experience and expertise to understand and appropriately consider the reliability and relevance of the company's financial reporting and compliance with the relevant accounting standards. The committee will also need regularly to familiarise itself with the latest developments in accounting standards and reporting requirements, and be aware of the significant impact that the developments may have on financial reporting.

In their discussion paper on the Framework Convergence Project (referred to in section 2.3) the IASB places emphasis on "financial reporting" rather than "financial statements" (IASB, 2006:0B2). This emphasis implies a move away from traditional financial statements, and implies that the financial reporting process in the future will also include other documents, such as management commentary, that have traditionally not formed part of the financial statements (Heathcote \& Human, 2008:25). This development is further supported by the King III Report on Corporate Governance (draft) issued on 25 February 2009 in South Africa, which places emphasis on integrated sustainability reporting (Institute of Directors (hereafter IoD), 2009:15).

These developments will, inter alia, imply extended responsibilities for audit committees, focusing not only on accounting standards and financial statements, but on other areas of financial reporting as well. In this regard King III (draft) now tasks the audit committee with overseeing stakeholder reporting, which includes financial reporting, the interim results, summarised financial reporting and integrated sustainability reporting (IoD, 2009: Code, paragraph 3.4). The new Companies Act, signed by the President on 08 April 2009 (Republic of South Africa, 2008) now also requires in section 94(7f) a report of the audit committee in the financial statements commenting on, inter alia, the financial statements and accounting practices of the company. (Marx, 2008:175-207).

From the above discussion it is evident that audit committees should in future not only have a sound understanding of accounting standards and their applications, but also of other financial reporting requirements such as sustainability and environmental reporting issues This would require the audit committee to consist of members who are financially literate and with the relevant financial (and corporate governance) expertise amongst their ranks to deal with their 
extended financial oversight reporting responsibilities such as sustainability aspects.

\subsection{Description of the terms 'financial literacy' and 'financial expertise' for audit committee members}

The audit committee has an important financial oversight responsibility in relation to financial reporting and accordingly (and as discussed in sections $2.1-2.5$ ) it is essential that members have the necessary understanding, experience and expertise regarding financial reporting, and control-and audit-related aspects. In the light of the significant and complex changes to accounting standards it is important (and arguably critical) for audit committee members to be financially literate and for audit committees to have the necessary financial expertise amongst their members.

Various definitions have been ascribed to these concepts by corporate governance codes and legislation around the world (Marx, 2008:47-49; 569). The following definitions are, although quite old, considered to be the most descriptive. It should be noted that no such descriptions or definitions are currently provided for by legislation, regulation or corporate governance codes in South Africa. The Companies Act of 2008 (Republic of South Africa, 2008) states in section 94(5) only that: "the Minister may prescribe minimum qualification requirements for members of an audit committee as necessary to ensure that any such committee, taken as a whole, comprises persons with adequate relevant knowledge and experience to equip the committee to perform its functions". The King III Report (draft) on Corporate Governance (IoD, 2009: Chapter 3: principle 4.2) states that it is best practice that "audit committee members have the necessary level of financial literacy", while the Code requires that "audit committee members should be suitably skilled and experienced independent non-executive directors" (IOD, 2009: Code, principle 3.2).

Financial literacy for audit committee members has been usefully explained by the Blue Ribbon Committee in the US as "The ability to read and understand fundamental financial statements, including a company's balance sheet, income statement, and cash flow statement" (Brewer, 2001:39; Blue Ribbon Committee, 1999:26). The same essential meaning of financial literacy is used by the Australian Securities Exchange (hereafter ASX) Corporate Governance Council: "to be able to read and understand financial statements" (ASX Corporate Governance Council, 2007: recommendation 4.2).

Financial expertise is explained as follows by the Blue Ribbon Committee in the US, a definition that is basically followed in the Sarbanes-0xley Act: "Past employment experience in finance or accounting, requisite professional certification in accounting, or any other comparable experience or background which results in the individual's financial sophistication, including being or having been a CEO or other senior officer with financial oversight responsibilities" (Brewer, 2001:39; Blue Ribbon Committee, 1999:26).

\section{THE ROLE OF THE AUDIT COMMITTE\& TO ENSURE ACCURATE, CREDIBLE AND RELIABLE FINANCIAL REPORTING}

Various corporate governance codes, legislation and regulations, both in South Africa and internationally, have provided recommendations on the audit committee's responsibilities. In essence these are best illustrated by the recommendations of the Combined Code in the United Kingdom (Financial Reporting Council, 2006:paragraph C3.2), which reflects those of the Smith 
Report on audit committees in the United Kingdom (Smith, 2003), and which set the standard for modern audit committee practices worldwide:

- "To monitor the integrity of the financial statements of the company and any formal announcements relating to the company's financial performance, reviewing significant reporting judgements contained in them;

- To review the company's internal financial controls and unless expressly addressed by a separate board risk committee composed of independent directors, or by the board itself, to review the company's internal control and risk management;

- To monitor and review the effectiveness of the company's internal audit function;

- To make recommendations to the board, for it to put to the shareholders for their approval in general meeting, in relation to the appointment, re-appointment and removal of the external auditor and to approve the remuneration and terms of engagement of the external auditor.

- To review and monitor the external auditor's independence and objectivity and the effectiveness of the audit process, taking into consideration relevant United Kingdom professional and regulatory requirements;

- To develop and implement a policy on the engagement of the external auditor to supply non-audit services, taking into account relevant ethical guidance regarding the provision of non-audit services by the external audit firm."

In addition to the above the audit committee is often tasked these days with dealing with confidential reporting by employees regarding questionable accounting or auditing matters ('whistle blowing').

It is suggested in the literature that audit committees are not always constituted effectively, and that their members often lack the necessary financial experience and expertise (Casarino \& Van Esch, 2005:179; Ferreira, 2008:89-90; Marx, 2008:21-27, 47-49, 540-568). Given the responsibilities of audit committees as stated above, and the complexity of financial reporting as discussed, this would be a critical factor regarding the effectiveness of audit committees. Accordingly, the constitution of audit committees and the qualifications of their members are empirically analysed in the remainder of the article.

\section{METHODOLOGY FOR THE EMPIRICAL STUDY}

\subsection{Population used in the empirical study}

The empirical study focused on audit committees at large listed companies in South Africa and accordingly the population for the empirical study was the largest 40 companies ranked by market capitalisation in the JSE's All-Share Index (referred to as the FTSE/JSE Top 40 Index) (JSE 2007b:12-13). On 28 November 2007 the companies of the FTSE/JSE Top 40 Index represented $86.39 \%$ of the total market value of the JSE's All-Share Index (JSE, 2007a) and on 27 February 2008 they represented $87.64 \%$ (JSE, 2008a; JSE, 2008b). From these statistics it is evident that the companies included in the population represent the largest companies in market value (almost $90 \%$ in total) on the JSE. All 40 companies in the stated population were included in the empirical study. 


\subsection{Nature of the empirical study}

The empirical study had two main thrusts: the inspection of the annual reports of the companies in the population between 25 and 28 March 2008, and the sending out of questionnaires in the first week of April 2008 to the audit committee chairs of these companies for completion. The audit committee chairs are considered to play an important role in the effective functioning of the audit committee, and accordingly they were selected as respondents for the questionnaire to test and solicit views on the effective constitution and functioning of their audit committees (Marx, 2008:349-351).

The aspects inspected in the annual reports and the questions included in the questionnaires were based on the information obtained from the literature study. There was a particular focus on those aspects in the annual reports that would contribute to the information that was solicited through the questionnaires.

\subsection{Empirical coverage and response rate}

All the annual reports of the companies in the population (40) were inspected, and these were the most recent reports that were available at the time ( $100 \%$ coverage). This was done at the offices of the JSE in Johannesburg, or on the companies' websites in cases where the latest annual reports had not yet been received by the JSE (companies have six months to submit hard copies of their financial statements to the JSE).

The questionnaires were e-mailed on 4 April 2008 to the chairs of the audit committees for completion, while personalised hard copies of the questionnaires were also sent by courier a week later directly to audit committee chairs in case they preferred to complete hard copies. For the questionnaires a response rate of $85 \%$ was achieved, as 34 out of 40 questionnaires were received back from the audit committee chairs. The response rate of $85 \%$ achieved for the study is deemed to be very high and should contribute to the reliability and usefulness of the information therein.

\section{FINDINGS OF THE EMPIRICAL STUDY}

\subsection{From the annual report analysis}

\subsubsection{Qualification of audit committee members}

The findings in TABLE $\mathbf{l}$ indicate that $41.9 \%$ of the members of the average audit committee (which was found to have an average size of 4.15 members) have at least a $B$ degree or higher in accounting, while $50.4 \%$ of members have a professional accounting qualification (CA, ACCA, FCA etc). A further analysis indicates that at least $66 \%$ of the members have a business-related degree ( $41.9 \%$ plus $24.1 \%$ ), which may be taken to imply that they should be able to read and understand financial statements, and therefore can be classified as financially literate. The highest number of members on an audit committee with a professional accounting qualification is seven (out of a total of eight members), while all the audit committees have at least one member with a professional accounting qualification. 
TABLE 1: Qualification of audit committee members

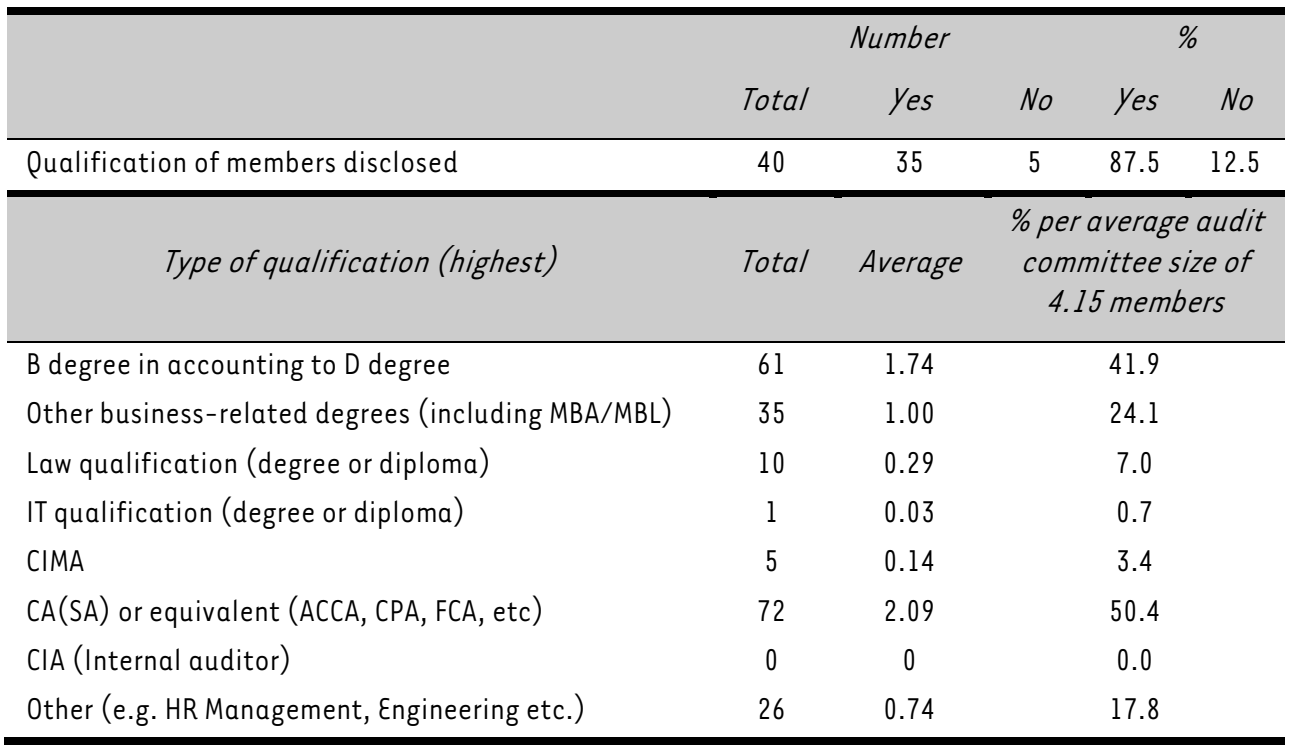

Source: Annual report disclosure (own analysis)

Given the growing importance of IT in the business environment, the lack of IT qualifications on the audit committee is apparent. Of interest is the fact that the other business-related degrees comprise mainly MBA qualifications. It is of some concern that certain members serving on the audit committee appear to lack accounting qualifications or experience. This might be so in fact, or such an impression might be created because of the poor quality of disclosure regarding their qualifications and/or experience.

As is evident from TABLE 1 , the average audit committee consists of at least two members who have a professional accounting qualification (CA, ACCA, FCA, etc.) and so would meet the requirements for financial expertise on the audit committee. It accordingly appears that there might not be a lack of members with financial expertise on audit committees.

\subsection{From the audit committee chair questionnaires}

\subsubsection{Effective constitution of audit committees}

From the findings in TABLE 2 it is evident that all the audit committee chairs are of the opinion that their audit committee members act independently $(100 \%)$, while the majority of them are of the opinion that the members have the right mix of experience $(97.1 \%)$ and financial literacy (97.1\%). Only one committee (2.9\%) lacks members with the right mix of experience and financial literacy, in the view of its chair.

31 of the committee chairs (91.2\%) are of the opinion that their committees consist of members with sufficient financial expertise (defined as formal qualifications in accounting and/or auditing) while three committees ( $8.8 \%)$ do not have sufficient expertise of this nature, in the view of their chairs. 
TABLE 2: Audit committee chairs' views on the effective constitution of their audit committees

\begin{tabular}{|c|c|c|c|c|c|}
\hline & \multicolumn{3}{|c|}{ Number } & \multicolumn{2}{|c|}{$\%$} \\
\hline & Total & yes & No & yes & No \\
\hline \multicolumn{6}{|l|}{$\begin{array}{l}\text { Are you of the opinion that your audit committee } \\
\text { consists of members: }\end{array}$} \\
\hline - Who act independently? & 34 & 34 & 0 & 100 & 0 \\
\hline $\begin{array}{l}\text { - Who have the right mix of appropriate } \\
\text { experience? }\end{array}$ & 34 & 33 & 1 & 97.1 & 2.9 \\
\hline $\begin{array}{l}\text { - Of sufficient number who are financially literate } \\
\text { (i.e. able to read and understand financial } \\
\text { statements)? }\end{array}$ & 34 & 33 & 1 & 97.1 & 2.9 \\
\hline $\begin{array}{l}\text { - Of sufficient financial expertise (i.e. formal } \\
\text { qualifications in accounting and/or auditing)? }\end{array}$ & 34 & 31 & 3 & 91.2 & 8.8 \\
\hline
\end{tabular}

Source: Audit committee chair questionnaire (own calculation)

This supports the view of the three audit committee chairs (8.8\%) that are of the opinion that their audit committees are not properly constituted.

\subsubsection{Audit committee member characteristics}

TABLE 3: Audit committee member characteristics

\begin{tabular}{|c|c|c|}
\hline $\begin{array}{c}\text { Audit committee members' characteristics (ranked } 1 \text { to } 9, \text { where } 1 \text { is } \\
\text { most important and } 9 \text { is least important) }\end{array}$ & Ranking & Value \\
\hline Personal attributes of members (integrity, diligence etc.) & 1 & 2.18 \\
\hline $\begin{array}{l}\text { Financial literacy (i.e. ability to read and understand financial } \\
\text { statements) }\end{array}$ & 2 & 2.56 \\
\hline Independence of members & 3 & 2.65 \\
\hline $\begin{array}{l}\text { Financial expertise (i.e. formal qualification in accounting and/or } \\
\text { auditing) }\end{array}$ & 4 & 3.71 \\
\hline Sufficient knowledge of the company's business and industry & 5 & 4.50 \\
\hline Availability of members' time & 6 & 4.97 \\
\hline Legal experience (formal qualification) & 7 & 6.88 \\
\hline Diversity in terms of race and gender & 8 & 8.09 \\
\hline Status/standing in the community & 9 & 8.18 \\
\hline
\end{tabular}

Source: Audit committee chair questionnaire (own calculation)

The above findings confirm the recommendations of the audit committee literature (Brewer, 2001; Ferreira, 2008; Marx, 2008; PricewaterhouseCoopers, 2005) that audit committee members should be individuals of eminent character who act with integrity, objectivity and honesty, are financially literate, independent and have the necessary financial expertise in their ranks (of least importance are race and gender issues and the individual's standing in the community). 


\subsubsection{Financial reporting-related responsibilities}

TABLE 4: Financial reporting-related responsibilities performed by the audit committee

\begin{tabular}{lcc}
\multicolumn{1}{c}{ Financial reporting-related responsibilities } & Number & $\%$ \\
\hline Review the appropriateness of the accounting policies applied? & 34 & 100 \\
Review the fair presentation of the annual financial statements? & 34 & 100 \\
Review the fair presentation of the interim financial statements? & 34 & 100 \\
Review the fair presentation of other financial reporting (e.g. profit & 32 & 94.1 \\
forecasts, prospectus)? & 32 & 94.1 \\
Review the going concern status applied in the financial statements?
\end{tabular}

Source: Audit committee chair questionnaire (own calculation)

The above findings indicate that all the audit committees (100\%) review the appropriateness of the accounting policies applied, the fair presentation of the annual financial statements and the interim financial statements, while 32 review the going concern status $(94.1 \%)$ and the fair presentation of other forms of financial reporting (94.1\%).

Audit committee chairs were also asked to indicate whether they are of the opinion that their audit committees are effective (to a large, or lesser extent), or ineffective in the performance of their financial reporting-related responsibilities. In total, $97.1 \%$ of the audit committee chairs were of the opinion that their audit committees are to a large extent effective in dealing with financial reporting matters, while $2.9 \%$ were of the opinion that their audit committees are effective to a lesser extent in this regard.

\subsubsection{Audit committee education and training}

TABLE 5: Audit committee education and training

\begin{tabular}{lcccccc}
\hline \multicolumn{1}{l}{ Audit committee education and training } & \multicolumn{3}{c}{ Number } & \multicolumn{3}{c}{$\%$} \\
& Total & yes & No & yes & No \\
\hline $\begin{array}{l}\text { Do all new audit committee members undergo an } \\
\text { induction process on audit committee-related issues? }\end{array}$ & 34 & 21 & 13 & 61.8 & 38.2 \\
$\begin{array}{l}\text { Do all members receive ongoing training on: } \\
\text { - Accounting matters? }\end{array}$ & 31 & 20 & 11 & 64.5 & 35.5 \\
- Auditing-related aspects? & 31 & 16 & 15 & 51.6 & 48.4 \\
- IFRS developments? & 33 & 25 & 8 & 75.8 & 24.2 \\
- Governance and regulatory requirements and & 33 & 23 & 10 & 69.7 & 30.3 \\
$\quad$ developments? & 31 & 23 & 8 & 74.2 & 25.8 \\
\hline
\end{tabular}

Source: Audit committee chair questionnaire (own calculation)

From the above findings it is evident that the audit committee education and training function 
is not as effective as expected, as only 21 respondents (61.8\%) have an induction process for new members with a relatively low provision of ongoing training. (Not all the respondents answered all of the sections; this accounts for totals of 31 and 33 responses.) Where training is provided it is normally arranged by the company secretary (43.6\%), the audit committee chair $(16.4 \%)$, the internal auditor $(10.9 \%)$, the financial director $(21.8 \%)$ and external consultants $(7.3 \%)$. Given the technical nature and complexity of financial reporting and the constant changes made to the accounting standards (as discussed in section 2), these findings are of concern as it is imperative for audit committee members to have a good understanding, and recent and up to date knowledge, of the accounting standards and other related aspects that affect the financial statements and financial reporting process. The importance of director training and development (which would include audit committee members) is also emphasised in King III (draft) (IoD, 2009:36-37)

\subsubsection{Compensation of audit committee members}

TABLE 6: Compensation of audit committee members

\begin{tabular}{|c|c|c|c|c|c|}
\hline & \multicolumn{3}{|c|}{ Number } & \multicolumn{2}{|c|}{$\%$} \\
\hline & Total & yes & No & yes & No \\
\hline $\begin{array}{l}\text { Do you feel that, in general, audit committee } \\
\text { members should receive higher compensation than } \\
\text { members of other subcommittees? }\end{array}$ & 34 & 33 & 1 & 97.1 & 2.9 \\
\hline Ifyes, why: & 33 & & & 100.0 & \\
\hline The higher level of expertise required? & 5 & & & 15.2 & \\
\hline The greater legal liability? & 1 & & & 3.0 & \\
\hline Both of the above? & 25 & & & 75.8 & \\
\hline Neither of the above? & 2 & & & 6.0 & \\
\hline $\begin{array}{l}\text { Do you feel that audit committee members may } \\
\text { receive share options as non-executive directors } \\
\text { while serving on the audit committee? }\end{array}$ & 34 & 4 & 30 & 11.8 & 88.2 \\
\hline $\begin{array}{l}\text { If yes, do you think it will impact on their } \\
\text { independence? }\end{array}$ & 4 & 0 & 4 & 0.0 & 100.0 \\
\hline
\end{tabular}

Source: Audit committee chair questionnaire (own calculation)

The above findings support those of the literature (Giles, 1998:8; Marx, 1995a:27; Marx, 1995b:32; Marx, 2008:208-210; Podgorski, 1983:11-12; Reinstein, 1980:13-15) which argue that the responsibilities of audit committee members are complex and onerous, and that they have a higher level of legal exposure than the members of other board committees, and that this warrants higher fees. These findings are also in line with those of recent surveys by Deloitte (2007:29) and PricewaterhouseCoopers (2007:53; 2009:18), which found that it is accepted practice that audit committee members are paid more than members of other board committees.

Only one audit committee chair (2.9\%) was of the opinion that audit committee members should not receive higher compensation than members of other committees (no motivation was 
provided for this reasoning), while 33 (97.1\%) were of the opinion that this should be the case. The majority ( $75.8 \%$ or 25$)$ ascribed the higher fees to the combined effect of the higher level of expertise required by audit committee members and the greater legal liability they are exposed to. Of interest is that 30 (or $88.2 \%$ ) of them felt that audit committee members should not receive share options as non-executive directors while serving on the audit committee. The reasoning they provided for this is that it could affect audit committee members' independence and objectivity.

\section{CONCLUSION}

The article has shown that accounting standards are undergoing constant change and have become very technical, which contributes to the complexity of modern financial reporting. This presents many challenges and difficulties to the preparers of financial statements and the audit committee as overseers of the financial reporting process. Given this situation, it is essential that audit committee members should be financially literate, and have the necessary financial expertise on the committee, to be effective in their oversight responsibility regarding financial reporting. Audit committee members should also be well compensated for their service on audit committees to take account of their specialised and complex responsibilities, time commitment and legal exposure.

The results from the empirical study supported the need for financial literacy and expertise of audit committee members, and indicated that the average audit committee at the largest listed companies in South Africa is composed of members who meet these requirements. It was further found that, given the complex nature of the audit committee's responsibilities and expertise, such members should receive higher remuneration than other committee members.

The findings of the study, however, must be treated with caution because the study was restricted to the largest listed companies in South Africa. Therefore, the results reported in this paper should not be generalised to smaller listed companies, unlisted entities or public sector institutions. Accordingly it is recommended that areas for future research should focus on the impact of accounting standards and financial reporting complexities on the audit committees at smaller companies, and public sector entities. Whether such committee members have the required financial experience and expertise as defined should also be investigated.

\section{REFERENCES}

American Institute of Certified Public Accountants. (AICPA). (1993). Meeting the Financial Reporting Needs of the Future. New York, USA.

Anonymous. (2008). SEC Publishes IFRS Roadmap. Accounting \& Business: 5.

ASX Corporate Governance Council. (2007). Corporate Governance Principles and Recommendations. $2^{\text {nd }}$ edition. Sydney: ASX Regulatory \& Public Policy Unit.

Blue Ribbon Committee. (1999). Report and Recommendations of the Blue Ribbon Committee on Improving the Effectiveness of Corporate Audit Committees. New York: New York Stock Exchange and the National Association of Securities Dealers. 
Brewer, F.C. (2001). Corporate audit committee effectiveness. Unpublished research report submitted in partial fulfilment of the requirements for the degree Masters of Commerce. Johannesburg: University of the Witwatersrand.

Casarino, R. \& Van Esch, S. (2005). Internal Auditing - An Integrated Approach. Landsdown: Juta \& Co. Carcello, J. (2003). Audit Committee Characteristics and Auditor Dismissals Following 'New' GoingConcern Reports. The Accounting Review. Available from: http://papers.ssrn.com/sol3/papers.cfm?abstract_id=323120. (Accessed 3 August 2006)

Deloitte. (2005a). IFRS in your pocket 2005. Hong Kong: Deloitte \& Touche Tomatso.

Deloitte. (2005b). IFRS and US GAAP. IAS plus. USA:IFRS Global Office.

Deloitte. (2006). Audit Committee Resource Guide. USA: Deloitte Development LLC. Member of Deloitte Touche Tohmatso.

Deloitte. (2007). Board structure and non-executive directors'fees. United Kingdom: Deloitte \& Touche LLP 2007.

Dilks, I. (2006, February). Don't forget the audience. Accounting \& Business, pp. 42-44.

Du Plessis, J., McConvill, J. \& Bagaric, M. (2005). Principles of contemporary corporate governance. Port Melbourne: Cambridge University Press.

Ernst \& Young. (2006). Transition to IFRS - The final analysis results. South Africa: Ernst \& Young.

Ernst \& Young. (2009). Managing risk in the current climate. BoardMatters Quarterly: Critical Insights for Today's Audit Committee. United Kingdom: EYGM Limited.

Ferreira, I. (2008). The effect of audit committees composition and structure on the performance of audit committees. Meditari, 16(2), pp. 89-106.

Financial Accounting Standards Board (FASB). (2008). Priorities of the Financial Accounting Standards Board. Available from: http://72.3.243.42/fasac/survey08.pdf. (Accessed 20 February 2009)

Financial Reporting Council. (FRC). (2006). The Combined Code of Corporate Governance. Available from: http://www.ecgi.org/codes/code.php?code_id=198. (Accessed 20 September 2007)

Giles, J.P. (1998). Evidence on the relationship between audit committee characteristics and the quality of financial reporting. Unpublished doctoral dissertation. New Jersey: State University of New Jersey

Gillingham, A. (2009, May 15). Spotlight on award winners. Business Day, p. 26.

Green, S. \& Gregory, H.J. (2005, February). The Ripple Effect. Internal Auditor, pp. 48-56.

Harding, F. (2000). Corporate Credibility - Why a Harmonised Global Accountancy Framework Matters. Available from: http://www.ifac.org/news/speecharticle.tmpl?nid=9599419216170. (Accessed 19 November 2002)

Heathcote, K.R. \& Human, E. (2008). Framework Fact File. Accountancy SA, pp. 24-27.

International Accounting Standards Board (IASB). (2002). Memorandum of Understanding. Available from: http://www.iasb.org/Current+Projects/Memorandum+of+Understanding+with+the+FASB.

(Accessed 12 February 2009) 
International Accounting Standards Board (IASB). (2006). Discussion paper: Preliminary Views on an improved Conceptual Framework for Financial Reporting: The objective of financial reporting and qualitative characteristics of decision-useful financial reporting information. London: IASB.

International Accounting Standards Board (IASB). (2008). Memorandum of Understanding progress report and timetable for completion. Available from:

http://www.iasb.org/Current+Projects/Memorandum+of+Understanding+with+the+FASB. (Accessed 12 February 2009)

Institute of Directors. (IoD). (2009). King Report on Corporate Governance. Johannesburg: Institute of Directors in Southern.

JSE Limited. (JSE). (2007a). LohnB@jse.co.za. 30 November 2007. Percentages. Email to marxb@mweb.co.za.

JSE Limited. (JSE). (2007b). Ground Rules for the Management of the FTSE/JSE Africa Index Series. Available from: http://ftse.jse.co.za/does/general_information/FTSE_SSE_Ground_Rules.pdf. (Accessed 27 February 2008)

JSE Limited. (JSE). (2008a). Indices constituents. Available from: http://fin.jse.co.za/findata/indicesconstituanse.asp?sectors=J300\&y=115-123-85-65-100-125119-89-82-66. (Accessed 27 February 2008)

JSE Limited. (JSE). (2008b). NongceboM@jse.co.za. 3 March 2008. Indices: Information request for study purposes. Email to marxb@mweb.co.za.

Klein, A. (2000). Audit committee, board of director characteristics, and earnings management. Research paper. New York University: Leonard N. School of Business.

KPMG. (2005). Toolkit for the audit committee. Johannesburg: KPMG.

Liu, M-H. C. (2005). The association of audit committee oversight with corporate disclosure quality. Unpublished doctoral dissertation. Buffalo: State University of New York.

Kukabadse, A. \& Korac-Kukabadse, W. (2002). Corporate governance in South Africa: Evaluation of the King II Report (Draft). Journal of Change Management, 2(4), pp. 305-316.

Marx, B. (1995a, December 8). Audit body could protect directors. F\&T Weekly, p. 27.

Marx, B. (1995b, December 15). Audit committee members and the law. F\&T Weekly, p. 32.

Marx, B. (2008). An analysis of the development, status and functioning of audit committees at large listed companies in South Africa. Unpublished doctoral thesis. Johannesburg: University of Johannesburg.

Marx, B. \& Lubbe, D.S. (1993). Enkele empiriese bevindinge aangaande die funksionering van ouditkomitees by groot maatskappye in Suid-Afrika. Meditari, 1(1), pp. 43-60.

Pacter, P. (2005) What exactly is convergence? Accounting and Performance Evaluation, 2(1,2), pp. 67-83.

Podgorski, J.M. (1983). The role of the audit committee in the internal control environment of a bank. Unpublished dissertation. University of Pennsylvania, Philadelphia: The Stonier Graduate School of Banking.

PricewaterhouseCoopers. (2005). Audit Committee Effectiveness - What works best, $3^{d}$ edition. New York: PricewaterhouseCoopers 
PricewaterhouseCoopers. (2006). Current developments for audit committees. New York: PricewaterhouseCoopers International Limited.

PricewaterhouseCoopers. (2007). Non-Executive Directors: Best Practices and Fees Report 2007. Johannesburg: PricewaterhouseCoopers.

PricewaterhouseCoopers. (2008). Catering for global standard setting. Governance and Corporate Reporting. World Watch. UK: PricewaterhouseCoopers.

PricewaterhouseCoopers. (2009). Non-Executive Directors: Best Practices and Fees Report 2007. Johannesburg: PricewaterhouseCoopers.

Rager, L.A. 2004. The effectiveness of independent audit committee directors with accounting certifications in preventing reporting irregularities in publicly traded companies. Unpublished doctoral dissertation. Davie, Florida USA: Nova Southeastern University

Republic of South Africa (2008). Companies Act, no. 71 of 2008, Government Notice 421. Government Gazette, no. 32121 of 2009. Pretoria: Government Printers.

Smith, R. (2003). Audit Committees Combined Code Guidance. The Financial Reporting Council. Available from: http://www.ecgi.org/codes/code.php?code_id=120. (Accessed 20 April 2007)

South African Institute of Chartered Accountants. (SAICA). (1994). Complying with the Financial Reporting Needs of Financial Statements in South Africa. Discussion Document 12. Johannesburg: South Africa.

South African Institute of Chartered Accountants. (SAICA). (2004). Status and effective dates of statements of Generally Accepted Accounting Practice (GAAP) and interpretations of statements of GAAP. Circular 07/04 SAICA Handbook, Volume 3 (2006/2007): 261-272. Durban: LexisNexis Butterworths.

South African Institute of Chartered Accountants. (SAICA). (2008). International Financial Reporting Standards (IFRS). SAICA Handbook, Volume 2. Durban: LexisNexis Butterworths.

Steenekamp, J. (2009). The road to one global accounting framework. Accountancy SA, pp. 28-29. Johannesburg: SAICA.

Spira, F. (2003). Audit Committees: begging the question. Corporate Governance: An International Review, 11(3), pp. 180-188. Available from: http://www.blackwellynergy.com/doi/abs/10.1111/1467-8683.00317?prevSearch $=\% 28 \% 28 \% 28$ author \%3A\%28Spira\%29\%29+AND+title $\% 3 A \% 28$ Audit+committees $\% 5$ C $\% 3 A+$ begging+the+question $\% 29 \% 29$ \%29. (Accessed 11 August 2007)

Reinstein, A. (1980). A conceptual framework for audit committees. Unpublished doctoral thesis. Kentucky: University of Kentucky.

Temkin, S. (2007, August 28). Audit firms look to ensure their survival. Business Day, p. 2.

Van der Linde, B. (2007, October). Technical update: South Africa. Accounting \& Business, p. 54.

Wayne, P.F. (2003). An investigation of the determinants of audit committee effectiveness. Unpublished doctoral dissertation. Toronto: York University.

Weiss, R. (2005). Audit committee characteristics and monitoring effectiveness. Unpublished doctoral dissertation. New York: City University of New York.

Wymeersch, દ. (2006). Corporate Governance Codes and their Implementation. Working Paper Series, WP 2006-10. Financial Law Institute. Belgium: University of Ghent. 
Yang, J.S. (2002). Audit Committees and Quarterly Earnings Management. Unpublished doctoral dissertation. Philadelphia, Pennsylvania: Temple University. 